\title{
A yeast protein that binds to vertebrate telomeres and conserved yeast telomeric junctions
}

\author{
Zhiping Liu and Bik-Kwoon Tye \\ Section of Biochemistry, Molecular and Cell Biology, Cornell University, Ithaca, New York 14853 USA
}

\begin{abstract}
We have identified three yeast proteins that bind to $\mathrm{poly}(\mathrm{C} \cdot \mathrm{A}) / \mathrm{poly}(\mathrm{T} \cdot \mathrm{G})$ repeats characteristic of telomeric sequences from yeast to human. TBFa binds to the telomeric sequences of yeast, Tetrahymena, and vertebrates. In contrast, TBF $\beta$ binds only to yeast telomeric sequences. Also identified was RAP1, the transcriptional silencer protein, which binds to a sequence motif found in upstream activating sequences (UASs) of a number of genes; the sequence motif also occurs frequently in yeast telomeric sequences. Because $\operatorname{poly}(\mathbf{C} \cdot \mathbf{A}) / \mathrm{poly}(\mathrm{T} \cdot \mathrm{G})$ sequences from a wide range of organisms will serve as the primer for the in vivo extension of telomeres in yeast, TBF $\alpha$ is of particular interest. DNase I footprinting analysis indicated that TBF $\alpha$ binds to the junction between the subtelomeric $X$ sequence and $\operatorname{poly}\left(\mathrm{C}_{1-3} \mathrm{~A}\right)$ in a cloned yeast telomere. Examination of the junctions of known $X$ sequences indicated that they all contain one or more repeats of CCCTAA, a sequence that is repeated in vertebrate telomeres. Earlier, Murray et al. (1988) reported that heterologous telomeric sequences positioned as far as several hundred base pairs from the termini of linear molecules can allow the addition of yeast telomeric sequences from nontelomeric termini in vivo. A possible function for TBFa might be to serve as an anchoring protein for the yeast telomerase by binding to the conserved junction sequence at a distance from the terminus to allow addition of an irregular repeating sequence at the chromosome end.
\end{abstract}

[Key Words: Telomere-binding factor; Saccharomyces cerevisiae; TBF $\alpha$; TBF $\beta$ telomere extension]

Received September 13, 1990; revised version accepted November 13, 1990.

Telomere structure had been described mostly in theoretical terms (Cavalier-Smith 1974; Bateman 1975; Dancis and Holmquist 1979) on the basis of our perception of the functions of telomeres (McClintock 1941; Watson 1972), until the work of Szostak and Blackburn (1982), who showed that termini from ribosomal DNA of Tetrahymena can serve as telomeres in the propagation of linear plasmids in yeast. Their work provides a means to physically isolate functional telomeres not only from yeast but also from heterologous systems using yeast as a host (Schechtman 1987; Richards and Ausubel 1988; Brown 1989; Cross et al. 1989|. Telomeres from a number of organisms have been cloned and characterized. They contain a tandem array of simple repeat sequences conforming to the general consensus $\left\langle\mathrm{C}_{1-8}\right)(\mathrm{T} / \mathrm{A})_{1-4}$, with a conserved sequence polarity of the G-rich strand running $5^{\prime}$ to $3^{\prime}$ toward the terminus. This simple repeat sequence is $\mathrm{C}_{1-3} \mathrm{~A}$ in the budding yeast Saccharomyces cerevisiae, $\mathrm{C}_{4} \mathrm{~A}_{2}$ in the ciliated protozoan Tetrahymena, and $\mathrm{C}_{3} \mathrm{TA}_{2}$ in human and all vertebrates examined so far. Sequence analysis of yeast-propagated Tetrahymena telomeres showed that these telomeres are chimeric products of Tetrahymena and yeast telomeric sequences with the yeast sequence added on to the Tetrahymena telomere (Shampay et al. 1984; Walmsley et al. 1984). Models invoking terminal exten- sion by terminal transferase (Shampay et al. 1984; Murray et al. 1988) or recombination (Walmsley et al. 1984; Pluta and Zakian 1989) were proposed to explain the addition of yeast telomeric sequences to heterologous telomeres.

Yeast telomeres are heterogeneous in length, ranging from 300 to $600 \mathrm{bp}$ (Chan and Tye 1983a). Work from this laboratory showed that $\mathrm{C}_{1-3} \mathrm{~A}$ repeat sequences of heterogeneous lengths are not only found in the extreme termini of chromosomes but also at the junctions of moderately repetitive and highly conserved subtelomeric sequences $\left(X\right.$ and $\left.Y^{\prime}\right)$ next to autonomously replicating sequences (ARSs) (Fig. 1); (Walmsley et al. 1984; Chan 1985). No functions have yet been identified for the subtelomeric repetitive sequences. Because of the variation in their copy number (0-4) from telomere to telomere and complete absence in certain yeast strains, the $Y^{\prime}$ sequences-were suggested to be derived from mobile elements that had high sequence specificity for integration at chromosome ends (Horowitz and Haber 1985; Jager and Philippsen 1989). The internal $\left(\mathrm{C}_{1-3} \mathrm{~A}\right)_{n}$ sequences were suggested to be the reservoir for telomeric sequences in the templated extension and unequal exchange models (Walmsley et al. 1984). Although numerous reports indicate that yeast telomeres undergo active recombinational exchanges (Dunn et al. 1984; 


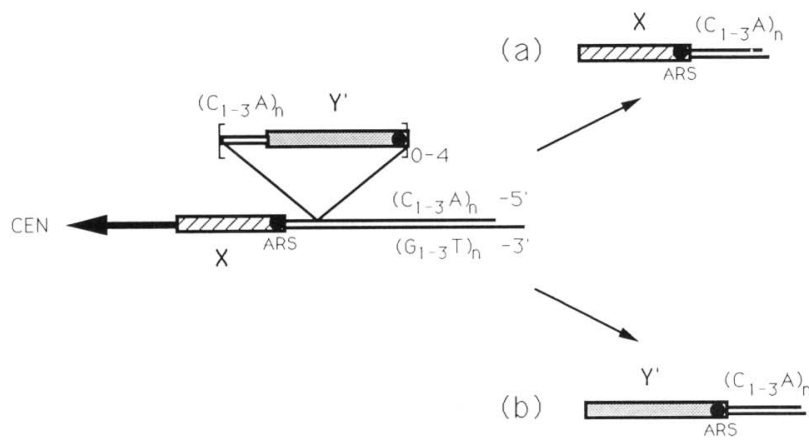

Figure 1. Structure of yeast telomeres. Yeast telomeres exist in either of two forms, $a$ or $b$. Y' sequences are highly conserved repetitive sequences $\sim 6.7 \mathrm{~kb}$ in length. $X$ sequences range from 0.5 to $4 \mathrm{~kb}$ in length, sharing varying degrees of homology to one another but no homology to $\mathrm{Y}^{\prime}$ sequences.

Pluta and Zakian 1989) allowing regeneration of telomeres (Surosky et al. 1986), the discovery of telomerase not only in Tetrahymena (Greider and Blackburn 1985) but also in human (Morin 1989), suggests that telomerase probably plays a major role in the replication of yeast telomeres as well.

The first telomere terminal transferase or telomerase activity was identified in Tetrahymena (Greider and Blackburn 1985). This activity is most abundant during macronuclear development of Tetrahymena when a large number of telomeres are formed and replicated. It is capable of adding tandem repeats of $\mathrm{G}_{4} \mathrm{~T}_{2}$ to singlestranded DNA primers corresponding to telomeric repeats of Tetrahymena $\left(\mathrm{G}_{4} \mathrm{~T}_{2}\right)$, independent of endogenous Tetrahymena DNA. Telomerase is a ribonucleoprotein enzyme containing multiple protein components and at least one RNA component (Greider and Blackburn 1989). In Tetrahymena, this RNA component is 159 nucleotides in length and contains the sequence $5^{\prime}$-CAACCCCAA- ${ }^{\prime}$ ' believed to serve as the template for the synthesis of GGGGTT repeats. Repeated translocation of the enzyme results in repeated synthesis of the same sequence. Thus, telomerase is a specialized reverse transcriptase carrying its own RNA template, which specifies the signature sequence polymerized at telomeres in different organisms. Attempts to identify yeast telomerase activity in this and several other laboratories have been unsuccessful. Recently, Lundblad and Szostak (1989) reported the isolation of a mutant est1, which shows a progressive decrease in telomere length and a senescence phenotype. Although EST1 has been cited as a possible candidate for a subunit of the telomerase complex, based on homology of the EST1 open reading frame to motifs found in RNA-dependent polymerases (Lundblad and Blackburn 1990), biochemical function for the EST1 gene product has yet to be identified. If replication of yeast telomeres is carried out by an enzyme similar to telomerase, this enzyme could have an imprecise translocation or copying mechanism, or there could be multiple telomerases carrying different RNA templates.
Telomeres undergo dynamic interactions between lengthening and shortening processes. Activities such as synthesis of repeat sequences and recombination by unequal exchanges can contribute to the lengthening of telomeres. Incomplete replication of the lagging daughter strand and exonucleolytic degradation result in shortening of telomeres. To maintain an optimal balance between these many metabolic processes that take place at telomeres, many proteins may be expected to interact directly with telomeric sequences. Work on Oxytricha showed that a heterodimeric protein binding tightly to the single-stranded 3 '-terminal $\left(\mathrm{G}_{4} \mathrm{~T}_{4}\right)_{2}$ tail may provide a telomeric capping function (Gottschling and Cech 1984; Gottschling and Zakian 1986). Previously, we have identified a telomere-binding activity from yeast extracts (Berman et al. 1986). This activity turned out to be the same as RAPl (Longtine et al. 1989), an abundant protein of $\sim 120 \mathrm{kD}$ (Shore and Nasmyth 1987). RAP1 binds to a consensus sequence that occurs in telomeric sequences, as well as in the silent mating type loci and in a number of gene promoters including TEF2 (Shore et al. 1987; Buchman et al. 1988a). On the basis of its binding specificities, RAPl has been suggested to play multiple roles in silencer function, transcriptional activation, and perhaps telomere maintenance. Re-examination of the properties of RAP1 led us to search for additional telomere-binding proteins. In this paper we describe our identification of two novel proteins, telomere-binding factors, TBF $\alpha$ and TBF $\beta$, and our studies on some of their properties. We discuss the possible function for one of these proteins, TBF $\alpha$.

\section{Results}

The binding of RAP1 to poly $\left(C_{1-3} A\right)$ is not sufficient for the mitotic segregation of plasmids

RAP1 binds to multiple sites on a $300-b p$ poly $\left(\mathrm{C}_{1-3} \mathrm{~A}\right)$ yeast telomeric sequence (Longtine et al. 1989). These binding sites conform to the consensus binding sequence $5^{\prime}-(\mathrm{A} / \mathrm{G})(\mathrm{A} / \mathrm{C}) \mathrm{ACCCANNCA}(\mathrm{T} / \mathrm{C})(\mathrm{T} / \mathrm{C})-3^{\prime}$ determined previously for the RAPI protein at the regulatory regions of the silent mating-type loci, $H M L \alpha$ and $H M R \alpha$, and other promoter sequences (Buchman et al. 1988a). Recent reports suggest that RAP1 may be associated with the nuclear scaffold (Hofmann et al. 1989). This scaffold association may explain the stability of plasmids containing the HMRE RAPl-binding site, which contributes a centromere-like segregation function (Brand et al. 1987; Kimmerly and Rine 1987). A plausible unified function served by RAP1 at the many seemingly unrelated locations is that it mediates scaffold associations at these sites. If telomeric sequences are also scaffold bound via the action of RAPl, they should exhibit the same centromere-like segregation behavior as HMRE. Thus, one would expect that poly $\mid \mathrm{C}_{1-}$ $\left.{ }_{3} \mathrm{~A}\right)$ would be antagonistic to the presence of "another" centromere, rendering CEN plasmids unstable, but would stabilize ARS plasmids without a centromere.

We cloned a poly $\left(\mathrm{C}_{1-3} \mathrm{~A}\right)$ sequence of $\sim 300 \mathrm{bp}$ con- 
taining multiple RAP1-binding sites from the left telomere of chromosome III into two almost identical plasmids: YRP74, which contains ARS1 URA3, and YCP86, which contains CEN3 ARS1 URA3 (plasmids were gifts from K. Struhl). As a control, we also cloned the $H M R E$ sequence into these same plasmids. The stabilities of the resulting plasmids were examined in transformed yeast strains. We found that poly $\left(\mathrm{C}_{1-3} \mathrm{~A}\right)$ does not possess centromere-like functions as observed in HMRE (Table 1, see YRP74 vs. pRHE3 and YCP86 vs. pCHE3). It neither stabilizes ARS plasmids (cf. YRP74 with pRYT3) nor destabilizes CEN plasmids (cf. YCP86 with pCYT3). These results suggest that either the binding of RAPl alone has no effect on plasmid segregation or that RAP1 does not bind to telomeric sequences in vivo. These results caution us not to overinterpret the role of RAP1 in telomere function based solely on its binding to poly $\left(\mathrm{C}_{1-3} \mathrm{~A}\right)$ sequences in vitro.

\section{RAP1 binds to yeast but not to other heterologous telomeric sequences}

Previous experiments showed that telomeric sequences from Tetrahymena (Szostak and Blackburn 1982), Oxytricha (Pluta et al. 1984), and human (Cross et al. 1989) can serve as primers for the extension of telomeres in yeast. We argue that proteins involved in the extension mechanism, whether as part of a telomerase-like machinery or a recombination machinery, should be able to bind to heterologous as well as yeast telomeric sequences. To further assess the role of RAP1 in telomere functon, we examined the binding specificity of RAPl and found that among all telomeric sequences tested, it binds only to the yeast sequence (Fig. 2a). This result suggested to us that there must be other yeast telomerebinding proteins with DNA-binding properties consistent with the in vivo data on telomere propagation in yeast. Carrying out the same experiment using crude extracts indicated that there are proteins that bind specifically to the human (lanes 2-4) and Tetrahymena (lanes 6-8) telomeric sequences in yeast (Fig. 2b). Furthermore, cross competition of these substrates (lane 9) suggested that the same protein or protein complex is re-

Table 1. Mitotic stability of plasmids bearing RAP1-binding sites

\begin{tabular}{lccc}
\hline Plasmid & Insert & CEN3 & $\begin{array}{c}\text { Stability } \\
(\%)^{\mathbf{a}}\end{array}$ \\
\hline YRp74 & - & - & $16.7 \pm 2.3$ \\
YCp86 & - & + & $91.6 \pm 1.6$ \\
pRHE3 & $H M R E$ & - & $85.7 \pm 1.8$ \\
pCHE3 & $H M R E$ & + & $19.6 \pm 0.7$ \\
pRYT3 & $\left(\mathrm{C}_{1-3} \mathrm{~A}\right)_{\mathbf{n}}$ & - & $19.3 \pm 1.1$ \\
pCYT3 & $\left(\mathrm{C}_{1-3} \mathrm{~A}\right)_{\mathbf{n}}$ & + & $71.6 \pm 2.6$ \\
\hline
\end{tabular}

aPercent of cells with plasmid after 10 generations of nonselective growth.

Plasmids were transformed into the yeast strain TDI (MAT $\alpha$ his4-32 trp1-289 ura3-52).

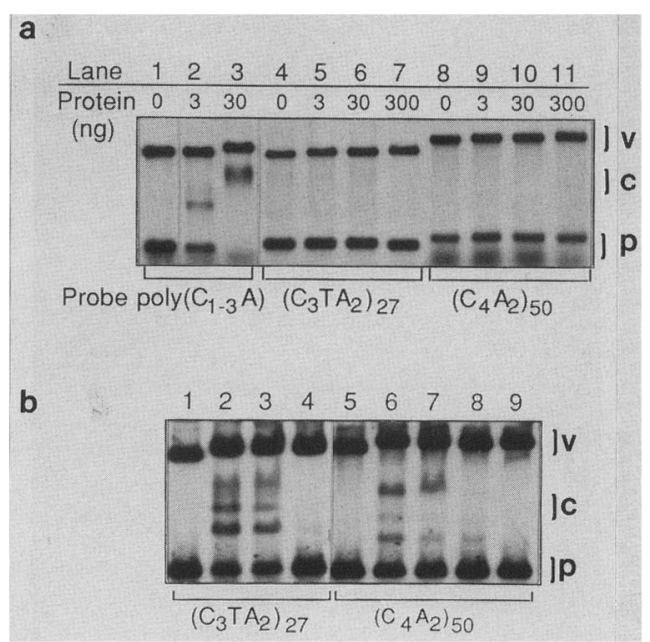

Figure 2. (a) Binding of RAP1 protein to different telomere sequences. The binding reaction includes 3 fmoles of specific telomeric DNA probes, $2 \mu \mathrm{g}$ of sonicated E. coli DNA, and partially purified $E$. coli-expressed RAP1 protein. (b) Telomerebinding activities in crude yeast extracts. The binding reaction includes 3 fmoles of telomeric DNA and $8 \mu \mathrm{g}$ (lanes $2-4$ ) or 16 $\mu \mathrm{g}$ (lanes $6-9$ ) of yeast extracts. Competitor DNA used are $2 \mu \mathrm{g}$ of sonicated E. coli DNAs (lanes 3 and 7), 100 fmoles of $\left(\mathrm{C}_{3} \mathrm{TA}_{2}\right)_{27}$ (lanes 4 and 9), or 100 fmoles of $\left(\mathrm{C}_{4} \mathrm{~A}_{2}\right)_{50}$ (lane 8). (v) Vector sequence; (c) protein-DNA complex; $(\mathrm{p})$ probe.

sponsible for the observed DNA-binding activity with specificity for telomeres in general.

\section{Other telomere-binding proteins}

Using different telomeric sequences as binding substrates in an agarose gel mobility shift assay (Berman et al. 1987), we were able to identify three activities from fractionated yeast extracts that bind to one or more of the telomeric sequences tested (Fig. 3a). Figure 3b shows the protein profile and the DNA-binding activity profile of eluates from phosphocellulose chromatography. The first activity peak (Fig. 3a, lanes 4-11) binds to the yeast telomeric sequence [ $138 \mathrm{bp}$ of poly $\left(\mathrm{C}_{1-3} \mathrm{~A}\right)$ and $27 \mathrm{bp}$ of $X$ sequence; Fig. $3 \mathrm{a}(\mathrm{D}))$, as well as a restriction fragment containing a RAP1-binding site within the UAS of the TEF2 gene [Fig. 3a(A)]. This activity peak has been confirmed as that of the RAP1 protein by antisera to RAP1 protein expressed in Escherichia coli (Z. Liu, unpubl.). The second activity peak, which we call TBF $\alpha$ (Fig. 3a, lanes 10-14) binds to telomeric sequences of yeast $\left[\right.$ poly $\left(\mathrm{C}_{1-3} \mathrm{~A}\right) \cdot \mathrm{X}$; Fig. 3a (D)], Tetrahymena $\left[\operatorname{poly}\left(\mathrm{C}_{4} \mathrm{~A}_{2}\right)\right.$; Fig. $3 \mathrm{a}(\mathrm{C})]$, and human $\left[\right.$ poly $\left(\mathrm{C}_{3} \mathrm{TA}_{2}\right) ;$ Fig. $\left.3 \mathrm{a}(\mathrm{B})\right]$. Like RAP1, the third activity peak, TBF $\beta$ (lanes $17-20$ ), binds only to the yeast telomeric sequence, but unlike RAP1, it does not bind to TEF2. Immunoprecipitation of fraction II incubated with yeast and vertebrate telomeric sequences using RAP1 antibody enriches for the poly $\mid \mathrm{C}_{1-}$ $\left.{ }_{3} \mathrm{~A}\right)$-binding activity but not the poly $\left(\mathrm{C}_{3} \mathrm{TA}_{2}\right)$-binding activity (data not shown). Thus, all three proteins, RAPl, $\mathrm{TBF} \alpha$, and TBF $\beta$, bind to poly $\left(\mathrm{C}_{1-3} \mathrm{~A}\right) \cdot \mathrm{X}$ but can be dif- 

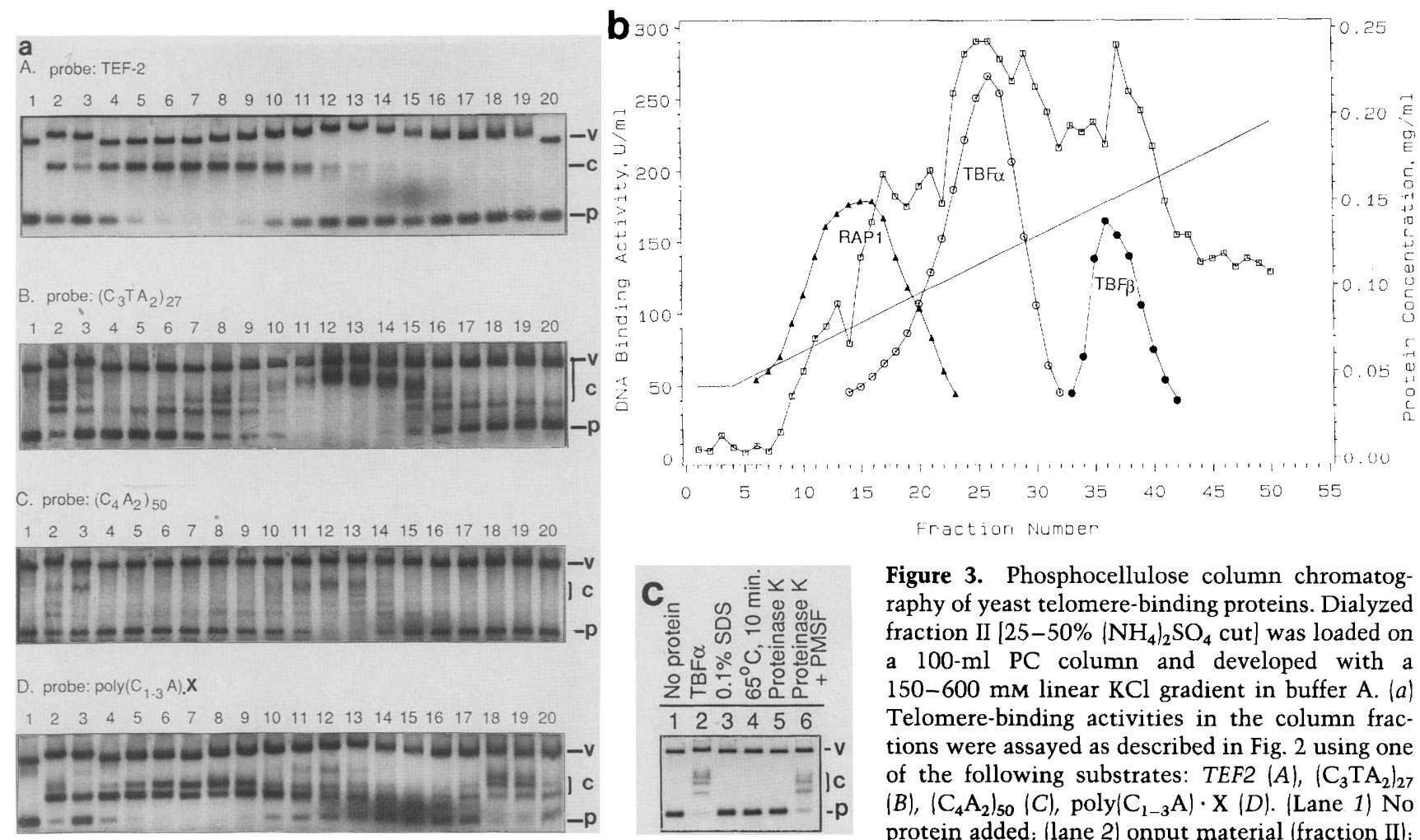

Figure 3. Phosphocellulose column chromatography of yeast telomere-binding proteins. Dialyzed fraction II $\left[25-50 \%\left(\mathrm{NH}_{4}\right)_{2} \mathrm{SO}_{4}\right.$ cut] was loaded on a 100-ml PC column and developed with a 150-600 mM linear $\mathrm{KCl}$ gradient in buffer A. (a) Telomere-binding activities in the column fractions were assayed as described in Fig. 2 using one of the following substrates: TEF2 $(A),\left(\mathrm{C}_{3} \mathrm{TA}_{2}\right)_{27}$ $(B),\left(\mathrm{C}_{4} \mathrm{~A}_{2}\right)_{50}(C)$, poly $\left(\mathrm{C}_{1-3} \mathrm{~A}\right) \cdot \mathrm{X}(D)$. (Lane 1) No protein added; (lane 2) onput material (fraction II);

(lane 3) flowthrough from PC column; (lanes 4-20) even-numbered fractions from 8 to 40 . A 10- $\mu$ l aliquot of the fractions was added to each binding reaction. The same lane in each panel corresponds to the same fraction assayed. (v) Vector sequence; (c) complex; $(p)$ probe. $(b)$ Elution profiles of the different telomere-binding activities in PC chromatography. All column fractions were assayed. RAP1 was determined by binding activity to the TEF2 promoter. TBF $\alpha$ was determined by binding activity to $\left(\mathrm{C}_{3} \mathrm{TA}_{2}\right)_{4}$, which coincides with that for $\left(\mathrm{C}_{3} \mathrm{TA}_{2}\right)_{27}$ and $\left(\mathrm{C}_{4} \mathrm{~A}_{2}\right)_{50}$ in $a$. TBF $\beta$ was determined as binding activity that binds only to poly $\left(\mathrm{C}_{1-3} \mathrm{~A}\right) \cdot \mathrm{X}$. ( $\left.\square\right)$ The protein concentration in each fraction. (c) Inactivation of TBF $\alpha$-binding activity. Agarose gel band-shift assay was carried out as in $a$ using $\left(\mathrm{C}_{3} \mathrm{TA}_{2}\right)_{27}$ as substrate. (Lane 1) No protein; (lanes 2-6) TBFo (1 $\mu \mathrm{g}$ fraction III). Inactivation by $0.1 \%$ SDS (lane 3$) ; 65^{\circ} \mathrm{C}, 10 \mathrm{~min}($ lane 4); $1 \mu \mathrm{g}$ proteinase $\mathrm{K}, 26^{\circ} \mathrm{C} 10 \mathrm{~min}$ (lane 5); $1 \mu \mathrm{g}$ proteinase $\mathrm{K}+1 \mathrm{mM}$ PMSF (lane 6).

ferentiated from one another based on their DNAbinding specificities for other substrates, their antigenicity, and their distinct chromatographic behavior on phosphocellulose chromatography (Fig. 3b).

We pooled the peak fractions of TBF $\alpha$ and showed that this binding activity to poly $\left(\mathrm{C}_{3} \mathrm{TA}_{2}\right)$ is sensitive to SDS, heat, and proteinase $\mathrm{K}$ treatment (Fig. 3c, lanes 3-5). The effect of proteinase $\mathrm{K}$ on the binding activity was specific, because the presence of a serine protease inhibitor blocked the inactivation (lane 6). These results suggest that $\mathrm{TBF} \alpha$ is a protein or at least contains a protein component.

\section{TBFa is distinct from the RAP1 protein}

Because of the abundance of RAPl, the TBF $\alpha$ activity peak (fraction III) from the phosphocellulose column is still rich in the RAP1 protein. To purify TBF $\alpha$ from RAP1, we carried out DNA column chromatography (Alberts and Herrick 1971) by passing fraction III through a DNA cellulose column coupled with plasmid DNA containing $\left(\mathrm{C}_{3} \mathrm{TA}_{2}\right)_{27}$. Because RAP1 does not bind specifically to poly $\left(\mathrm{C}_{3} \mathrm{TA}_{2}\right)$, it was eluted at low salt, whereas $\mathrm{TBF} \alpha$ was eluted at higher salt as a sequence- specific binding protein. The column fractions were tested for binding to DNA fragments containing TEF2, yeast telomeric sequence, $\left(\mathrm{C}_{3} \mathrm{TA}_{2}\right)_{4}$, and $\left(\mathrm{C}_{4} \mathrm{~A}_{2}\right)_{50}$. Figure 4 shows that RAPl, which binds to TEF2 and poly $\left(\mathrm{C}_{1-}\right.$ ${ }_{3}$ A) (lanes $4-8$ ), is clearly separated from TBF $\alpha$, which binds to all three telomeric sequences (lanes 11-17). RAPl formed at least two complexes with the yeast sequence that contains two strong and one weak RAP1binding sites (Fig. 4D, lane 7). In contrast, TBF $\alpha$ only formed one complex with the same sequence (lane 12), suggesting that this sequence contains only one binding site for TBF $\alpha$. Although TBF $\alpha$ formed a single DNAprotein complex when bound to either the yeast sequence or $\left(\mathrm{C}_{3} \mathrm{TA} \mathrm{A}_{2}\right)_{4}$, it formed multiple DNA-protein complexes when bound to $\left(\mathrm{C}_{4} \mathrm{~A}_{2}\right)_{50}$. Because the binding activity profiles for all three substrates are coincident, we believe that the mulitple shifts seen in the binding of poly $\left(\mathrm{C}_{4} \mathrm{~A}_{2}\right)$ are due to the presence of multiple $\mathrm{TBF} \alpha-$ binding sites on this sequence.

$T B F a$ DNA-binding activity copurifies with a $63-k D$ protein

Because the DNA-binding activity of $\mathrm{TBF} \alpha$ is sensitive 


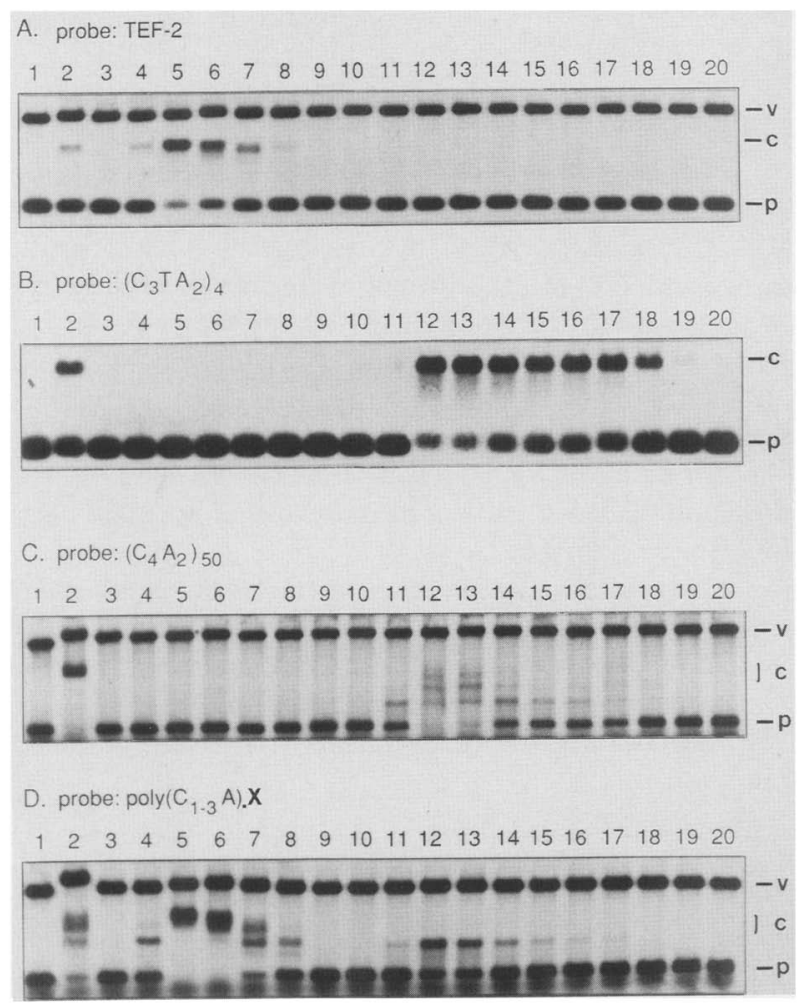

Figure 4. DNA column chromatography of TBF $\alpha$. Fraction III was loaded onto a plasmid DNA column containing $\left(\mathrm{C}_{3} \mathrm{TA}_{2}\right)_{27}$. After an extensive wash at $0.1 \mathrm{M} \mathrm{KCl}$, the column was developed using two linear $\mathrm{KCl}$ gradients, $0.1-0.3 \mathrm{M}$ and $0.3-0.6 \mathrm{M}$, with a three-column wash at $0.3 \mathrm{M} \mathrm{KCl}$ in between. The elution of RAPl and TBF $\alpha$-binding activities was monitored by agarose gel band-shift assay with four different DNA probes 3 fmoles DNA per binding reaction), shown as four different panels. A $10-\mu l$ aliquot of the fractions was added to each binding reaction. (Lane 1) No protein added; (lane 2) onput material (fraction III); (lanes 3-8) even-numbered fractions from the low salt gradient; (lanes 9 and 10 ) fractions from $0.3 \mathrm{M} \mathrm{KCl}$ step wash; (lanes 11-20) even-numbered fractions from the high salt gradient elution. (v) Vector DNA; (p) probe DNA; (c) proteinDNA complex.

to proteinase $\mathrm{K}$ treatment, we wanted to identify the polypeptide that copurifies with the binding activity by examining column fractions using SDS-polyacrylamide gel electrophoresis. To remove DNA released from the DNA column as a result of nuclease contamination in fraction III, we pooled the activity peak (fraction IV) of $\mathrm{TBF} \alpha$ resolved by DNA chromatography and once again passed it through a phosphocellulose column. The TBF $\alpha$ activity, assayed by gel shift (Fig. 5 b, fractions $15-20$ ), copurifies with a protein with an apparent molecular mass of $63 \mathrm{kD}$ (Fig. 5a, fractions 15-20), which is considerably lower than that of RAP1 $(120 \mathrm{kD}$; Shore and Nasmyth 1987). This $63-\mathrm{kD}$ protein also copurifies with the TBF $\alpha$-binding activity on the DNA column (data not shown). There are other minor proteins that seem to copurify with this activity. At this time we are unable to discern whether $\mathrm{TBF} \alpha$ contains multiple subunits or whether these copurified proteins are mere contaminants. Estimation of the cellular concentration of $T B F \alpha$, on the basis of pmoles of substrate shifted per cell in gel shift assays, indicates that there are at least 50 molecules of TBF $\alpha$ per cell. The TBF $\alpha$ activity in fraction IV is purified $>5000$-fold and was used in all subsequent work described below unless otherwise specified. Details on the purification of $\mathrm{TBF} \alpha$ will be published elsewhere.

\section{TBFa binds to the junction between the subtelomeric} $\mathrm{X}$ and the poly $\left(C_{1-3} A\right)$ sequence

Because TBF $\alpha$ is a yeast protein, it is important to determine where it binds in the yeast telomere. DNase I footprinting analysis was carried out using a DNA fragment containing $27 \mathrm{bp}$ of $X$ sequence and $63 \mathrm{bp}$ of poly $\left(\mathrm{C}_{1-3} \mathrm{~A}\right)$ (see Fig. 1; Berman et al. 1986). This DNA fragment incubated with TBF $\alpha$ in a gel shift assay gives a single retarded complex in a reaction when $>50 \%$ of substrate is bound (Fig. 4D, lane 12). DNase I protection of both the

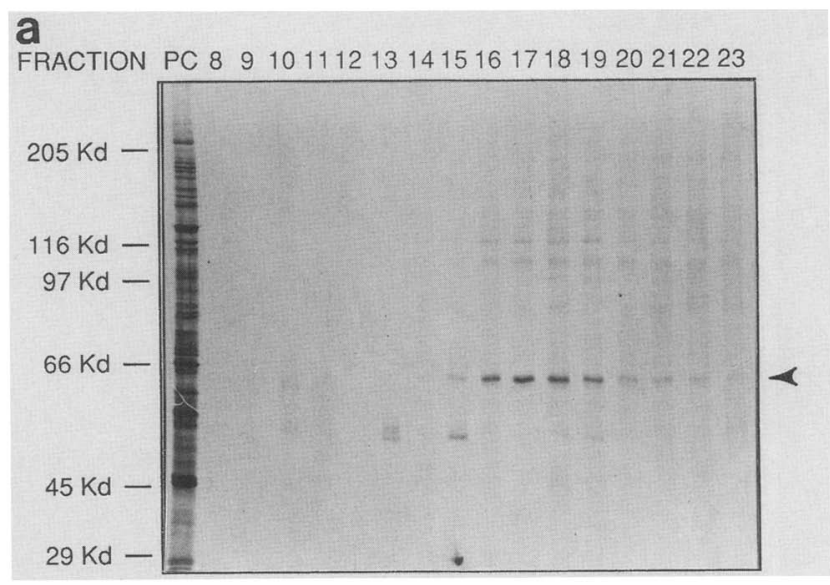

b

FRACTION PC 891011121314151617181920212223

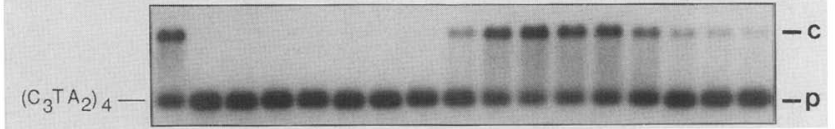

Figure 5. A $63-\mathrm{kD}$ protein copurified with $\mathrm{TBF} \alpha$-binding activity. The DNA column fractions containing TBF $\alpha$-binding activity were pooled (fraction IV) and concentrated on a $1.0-\mathrm{ml}$ phosphocellulose column. TBF $\alpha$ was eluted with a $0.15-0.6 \mathrm{M}$ linear $\mathrm{KCl}$ gradient. (a) Silver staining of the elution profile. Aliquots of $70-\mu \mathrm{l}$ of each fraction, from fraction 8 to 23 , were precipitated with $15 \%$ TCA, resuspended in cracking buffer, and loaded on a $8 \%$ SDS-polyacrylamide gel. [Lane 1 (PC)] $6 \mu \mathrm{g}$ protein from fraction III (DNA column onput) was loaded. Arrowhead indicates position of $63-\mathrm{kD}$ protein. $(b)$ Agarose gel band-shift assay for the column fraction. A 5- $\mu$ l aliquot of each fraction, from fractions 8 to 23 , was added to the binding reaction containing 3 fmoles of $\left(\mathrm{C}_{3} \mathrm{TA}_{2}\right)_{4}$ oligonucleotide, and proceeded as described in Materials and methods. (Lane 1) The binding reaction contained $1.2 \mu \mathrm{g}$ proteins from fraction III and $3 \mathrm{fmoles}$ of $\left(\mathrm{C}_{3} \mathrm{TA}_{2}\right\rangle_{4}$ oligonucleotide. 
C-rich (Fig. 6a, left) and the G-rich (Fig. 6a, right) strands is shown. A region of $\sim 34$ bp located at the junction of $X$ and poly $\left(\mathrm{C}_{1-3} \mathrm{~A}\right)$ sequence is protected from DNase I digestion by TBF $\alpha$. There are two copies of the sequence $\operatorname{ACCCTA}(\mathrm{A} / \mathrm{C})$ located in this protected region at the junction (Fig. 6b). Although gel shift assay indicates that there is only a single retarded complex formed under the condition in which the footprinting was carried out, we believe that this region consists of two tandem footprints of TBF $\alpha$, one (I) spanning the junction sequence (J) and another (II) lying within the $X$ sequence, each pro-

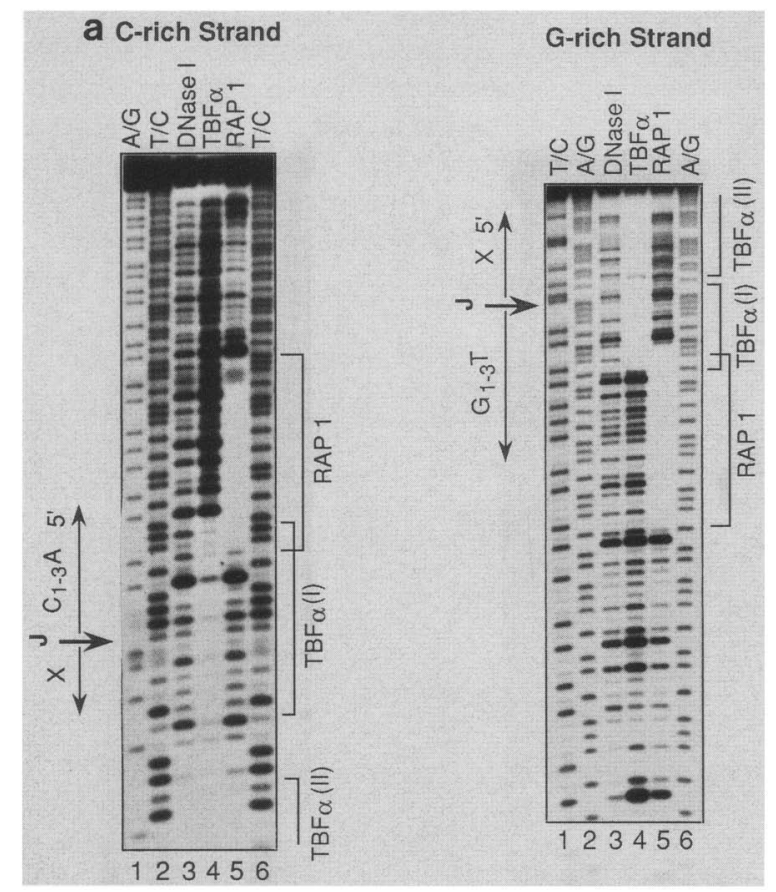

b

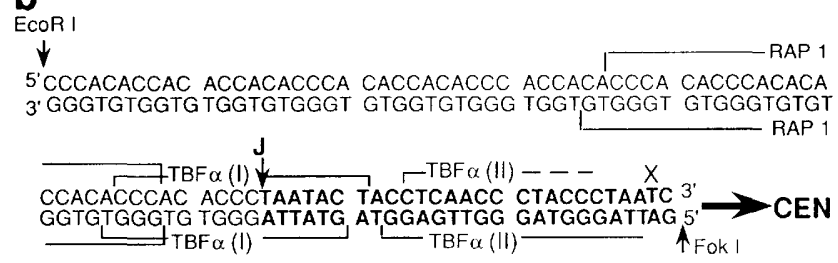

Figure 6. TBF $\alpha$ binds to the junction of the yeast telomeric sequence 120. (a) The C-rich and G-rich strands of the EcoRIFokI fragment were 3 -end-labeled by filling in with reverse transcriptase and incubated with TBF $\alpha$ or RAP1. (Lanes 3-5) DNase I digestion patterns observed in the absence (lane 3) or presence of TBF $\alpha$ (lane 4 and RAP1) (lane 5). (Lanes 1, 2, and 6) Maxam-Gilbert chemical sequencing ladders. Nonspecific competitor: (Lane 3) $0.2 \mu \mathrm{g}$ E. coli DNA; (lane 4) $0.1 \mu \mathrm{g}$ E. coli DNA + $0.1 \mu \mathrm{g}$ pTEF2; (lane 5) $0.1 \mu \mathrm{g}$ E. coli DNA + $0.1 \mu \mathrm{g}$ pBHTl. Only one of the TBF $\alpha$ footprints (I) can be seen on the $\mathrm{C}$-rich strand because of the poor resolution of $3^{\prime}$-terminal nucleotides on a sequencing gel (left, lane 4). (b) Actual sequence of the EcoRI-FokI fragment containing the yeast telomeric sequence. $(J)$ junction between the $X$ and poly $\left(\mathrm{C}_{1-3} \mathrm{~A}\right)$ sequence. Brackets indicate the protected regions. The dotted line indicates inferred protection from protected region in the opposite strand. tecting a region of $\sim 15-17 \mathrm{bp}$, including the sequence ACCCTA(A/C) [Fig. 6a (right) lane 4]. Consistent with this belief is the presence of a 2-nucleotide spacing between the presumed tandem footprints. Furthermore, we were able to show that TBF $\alpha$ binds weakly to a synthetic oligonucleotide duplex corresponding to site I of the junction sequence (data not shown). These results suggest that TBF $\alpha$ either binds as a dimer or binds cooperatively as two monomers to the tandem sites at the telomeric junction. We noted that the boundaries of the $\mathrm{TBF} \alpha$ footprints on the C-rich and G-rich strands are staggered by 1 nucleotide (Fig. 6a,b).

Footprinting of RAP1 was included as a control. The 63-bp poly $\left(\mathrm{C}_{1-3} \mathrm{~A}\right)$ region contains a single RAP1-binding site (Fig. 6a, lanes 5). As a result, a single protected region corresponding to the RAP1-binding site can be seen in the DNase I protection experiment (Fig. 6a). The RAP1-binding site is distinct from the TBF $\alpha$-binding site (I) at the junction, but they overlap by 4 bp (Fig. 6 b), confirming that TBF $\alpha$ and RAP1 are two distinct telomerebinding proteins.

\section{Footprinting of $T B F a$ on the vertebrate telomere}

We have already shown that TBF $\alpha$ forms multiple retarded complexes with the vertebrate telomeric sequence (CCCTAA) $)_{27}$ (Fig. 2b, lane 2) but forms a single retarded complex with $(\mathrm{CCCTAA})_{4}$ in a gel shift assay (Fig. 5b). To examine the interaction of TBF $\alpha$ with the vertebrate telomeric sequence, we constructed a headto-tail dimer of the sequence $\left(\mathrm{C}_{3} \mathrm{TA} \mathrm{A}_{2}\right)_{4}$ bridged by a linker sequence to create two tandem discrete binding sites for TBF $\alpha$. Gel retardation assay suggests that these two sites are occupied as independent binding sites, giving rise to two species of retarded complexes (Fig. 7b). DNase I protection analysis indicates that there are two protected regions on this sequence, one on either side of the linker (Fig. 7a). At lower concentrations of TBF $\alpha$, each protected region is $\sim 17 \mathrm{bp}$ in length (Fig. 7a, lanes 3). However, at higher concentrations of $T B F \alpha$, the boundaries of each of the footprints are not as well demarcated (lanes 4). These larger footprints may result from alternate overlapping positions that TBF $\alpha$ can occupy within the 24-bp region containing the CCCTAA repeats. Another plausible explanation is that TBF $\alpha$ recruits other proteins to these sites at higher protein concentrations. We noticed that footprints on the G-rich and C-rich strands are staggered $\sim 5$ bases (Fig. 7 a) such that footprints on the C-rich strand extend several bases into the nontelomeric flanking sequences. This staggered protection of TBF $\alpha$ on complementary strands was not observed in the binding of TBF $\alpha$ to yeast telomeric junction sequences (Fig. 6b,c). This discrepancy perhaps reflects a structural difference in the bound regions between these two DNA duplexes.

An alignment of the $\mathrm{TBF} \alpha$ footprints from the yeast telomeric junction and vertebrate telomeric sequence indicates that TBF $\alpha$ binds to two-and-a-half repeats of the sequence CCCTAA, tolerating mismatches of as many as 4 bp in a 16-bp sequence (Fig. 7c). However, it is 

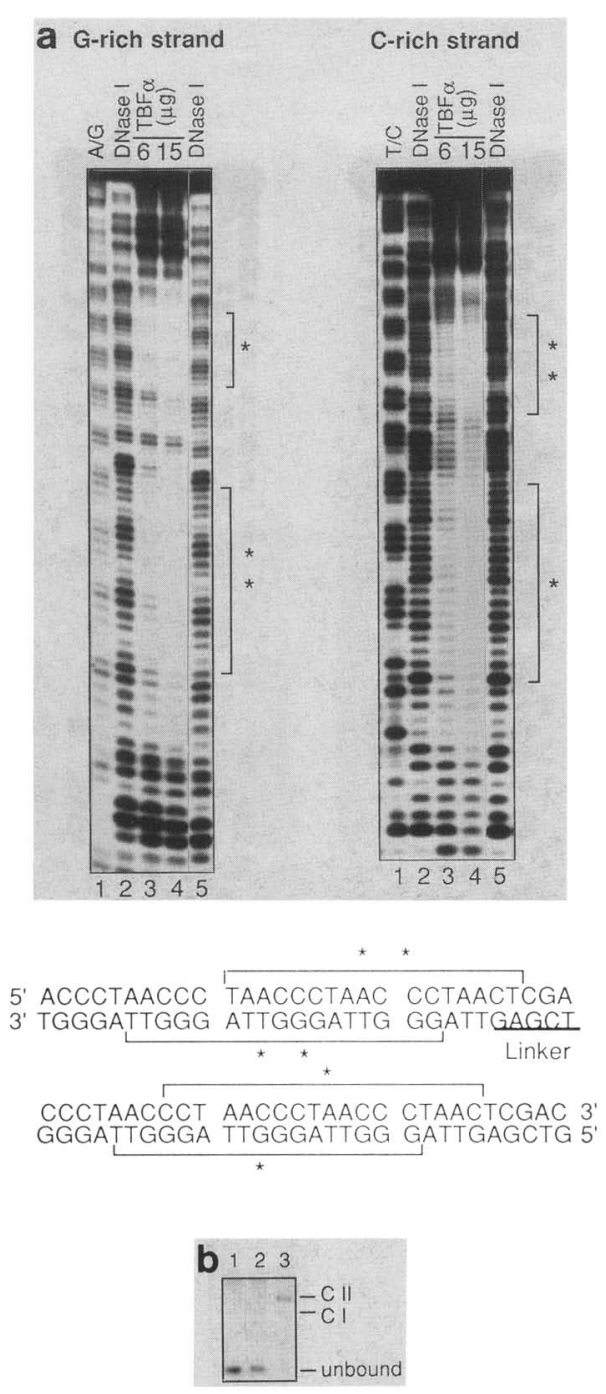

C

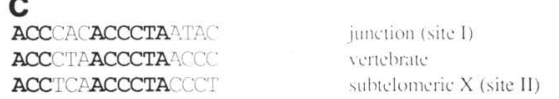

Figure 7. TBF $\alpha$ binds to vertebrate telomeric sequence. $(a)$ DNase I protection of vertebrate telomeric sequence by TBF $\alpha$. The (CCCTAA $)_{4}$ sequence was cloned into the Sall site in the Bluescript KS - vector. The C-rich and G-rich strands were $3^{\prime}$ end-labeled at the EcoRI and BanI sites by filling in with dNTPs using reverse transcriptase. (Lane 1) Maxam-Gilbert sequencing ladder; (lanes 2-5) DNase I digestion pattern in the absence (lanes 2 and 5) or presence (lanes 3 and 4) of TBF $\alpha$ (fraction III). Each footprinting reaction included $0.2 \mu \mathrm{g} \mathrm{E}$. coli DNA, 10 fmoles labeled DNA probe, and varying amounts of partially purified $\mathrm{TBF} \alpha$, as indicated. Brackets indicate $\mathrm{TBF} \alpha$ protected regions; ${ }^{*}$ and ** differentiate the two independent TBF $\alpha$-binding sites. (b) Gel retardation assay for TBF $\alpha$ binding to the footprinting probe used in $a$. Each binding reaction included 1 fmole of ${ }^{32} \mathrm{P}$-labeled DNA fragment and $0.5 \mu \mathrm{g} \mathrm{E}$. coli DNA. TBF $\alpha$ added no protein (lane 1); $0.4 \mu \mathrm{g}$ fraction III (lane 2); $1 \mu \mathrm{g}$ fraction III (lane 3). CI and CII represent TBF $\alpha / D N A$ complexes in which one or both TBF $\alpha$-binding sites are bound. (c) Comparison of TBF $\alpha$ footprints on yeast telomeric junctions (sites I and II) and vertebrate telomere. Bold type indicates sequence identity in the three footprints. not clear whether $\mathrm{TBF} \alpha$ will bind to the degenerate site (site II) in the $X$ sequence without the prior occupancy of the more conserved site (site I) at the yeast telomeric junction.

\section{TBFa binds to other highly conserved yeast telomeric junction sequences}

If TBF $\alpha$ plays an important role in telomeric function in yeast, we would expect TBF $\alpha$ to bind to all telomeric junctions and all telomeric junctions to be conserved. At least three subtelomeric $X$ sequences have already been determined. Two of the clones, 120 and $\mathrm{pD} 2$, were isolated as subtelomeric clones, but one of them, 3LT, contains the extreme terminus of the left telomere of chromosome III. A comparison of these known sequences indicates that the junction regions of $120,3 \mathrm{LT}$, and pD2 are highly conserved (Fig. 8a). Each of them contains a perfect repeat of the sequence CCCTAA at the junction next to additional degenerate repeats in the $X$ sequence.

On the basis of this sequence homology, we expected that TBF $\alpha$ would also bind to the telomeric junction of $3 \mathrm{LT}$, which contains four mismatches to the 120 sequence within the 34 -bp TBF $\alpha$-protected region. We made an oligonucleotide probe, T3LJD, the filling-in product of L3TJ, corresponding to this junction sequence of the left telomere of chromosome III /see 3LT junction sequence in Fig. 8a). TBF $\alpha$ binds to this sequence in a gel retardation assay (Fig. 8b, lane 2), and this binding is competed by yeast telomeric sequence (lane 4 ), the vertebrate telomeric sequence (lane 5), and the Tetrahymena telomeric sequence but not by E. coli DNA /lane 3 ), indicating that $\mathrm{TBF} \alpha$ is specific for telomeric sequences containing perfect or degenerate repeats of the sequence $\mathrm{CCC}(\mathrm{C} / \mathrm{T} \mid \mathrm{AA}$.

\section{Discussion}

We have identified two novel yeast telomere-binding proteins, TBF $\alpha$ and TBF $\beta$, which are distinct from RAP1, a previously identified telomere-binding protein. We are particularly interested in TBF $\alpha$ because it binds to the telomeric sequences of vertebrates, Tetrahymena, and yeast, all of which can serve as primers for the extension of telomeres in yeast. This correlation between the substrate requirement for telomere extension in vivo and the DNA-binding specificity of TBF $\alpha$ suggests that TBF $\alpha$ plays a role in the telomere extension process. TBF $\alpha$ binds either cooperatively as two monomers or as a single dimer to two adjacent sites in a cloned yeast subtelomeric sequence. One site lies within the $X$ sequence, and the other lies at the junction between the $X$ sequence and poly $\left(\mathrm{C}_{1-3} \mathrm{~A}\right)$. These tandem sites share extensive sequence similarities, both containing the ACCCTA motif, which is repeated in the human telomeric sequence.

The location of the TBF $\alpha$-binding sites prompted a closer examination of the junctions of three known telomeric clones, 120 (Walmsley et al. 1984), 3LT (Button and Astell 1986), and pD2 (Walmsley et al. 1984), all of 

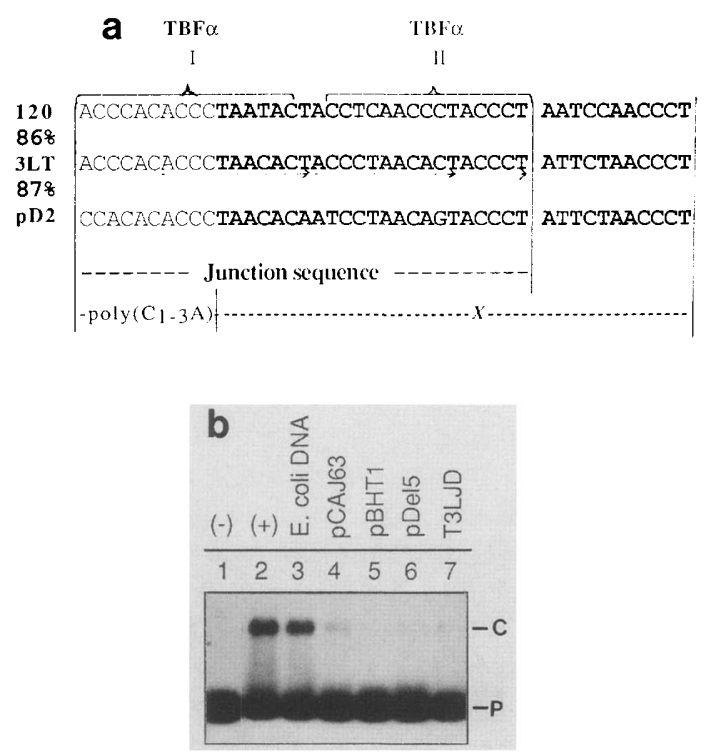

Figure 8. TBF $\alpha$ binds to the telomeric junction of the left arm of chromosome III. (a) Comparison of junction sequences from three yeast telomere clones, $120,3 \mathrm{LT}$, and $\mathrm{pD} 2$ containing $X$ sequences. $(\%)$ Percent identity shared by each pair of sequences. Brackets indicate TBF $\alpha$-protected regions, sites I and II. Bold type corresponds to $X$ sequences. Arrows indicate 11-bp direct repeats. $(b)$ Gel retardation assay for the specific binding of TBF $\alpha$ to $3 \mathrm{LT}$ junction and cross competition with other telomeric sequences. (Lanes 2-7) Each binding reaction includes 10 $\mu \mathrm{l}$ of fraction IV, 2 fmoles of ${ }^{32} \mathrm{P}$-labeled T3LJD oligonucleotide, and $1 \mu \mathrm{g}$ of sonicated E. coli DNA. Competitor DNAs added were $0.5 \mu \mathrm{g}$ sonicated E. coli DNA (lane 3); 200 fmoles linearized plasmid as specified (lanes 4-6); 500 fmoles completely filled-in T3LJ oligonucleotide (T3LJD) (lane 7).

which contain the repetitive $X$ sequence (Fig. 8a). The 120 and pD2 clones are subtelomeric in origin, whereas 3LT was originally isolated as the terminus of the left arm of chromosome III and therefore represents a true telomere (Fig. 1). In a 44-bp region at the junction, the homology between the subtelomeric sequences 120 and pD2 and the terminus of the left arm of chromosome III, $3 \mathrm{LT}$, is $86 \%$ and $87 \%$, respectively (Fig. $8 \mathrm{a}$ ). The natural telomere $3 \mathrm{LT}$ contains three copies of the sequence ACCCTA(A/T) which is, in turn, embedded within a larger 11-bp sequence repeated two-and-a-half times (Fig. $8 \mathrm{a}$, arrows). In contrast, the subtelomeric sequences 120 and $\mathrm{pD} 2$ each contain two copies of this sequence. The homology between the telomeric $X$ sequence 3LT and the subtelomeric $X$ sequence 120 is not limited only to the junction but extends for $\sim 770 \mathrm{bp}$ from the junction into the $X$ sequence, including the ARS sequence (see Fig. 1; V. Chang, unpubl.). Interestingly, within $\sim 200 \mathrm{bp}$ from the junction, these $X$ sequences are $\mathrm{C}$-rich on the poly $\left(\mathrm{C}_{1-3} \mathrm{~A}\right)$ strand and G-rich on the poly $\left(\mathrm{G}_{1-3} \mathrm{~T}\right)$ strand, characteristic of telomeric sequences, suggesting that they could be derived from telomeres. We have also inspected the nucleotide sequence of one subtelomeric $Y^{\prime}$ clone. It does not contain the sequence ACCCTAA at or near its junction (Chan 1985). However, we do not know whether the most distal $Y^{\prime}$ sequences located at the ends of chromosomes contain repeats of ACCCTAA at their junctions, as none of them has yet been identified.

What might be the function of TBF $\alpha$ that binds to the junction of the subtelomeric $X$ sequence and the telomeric repeats? If yeast also extends its telomeres by a telomerase enzyme, we suggest that it binds initially at a distance from the terminus and then extends from the terminus. In this model, TBF $\alpha$ serves as an anchor for telomerase by binding to the conserved telomeric junction to bring telomerase to the proximity of the terminus. This idea is appealing because in vivo data point to a need for telomerase to bind to a specific DNA sequence to act. In Tetrahymena, sequences derived from the sites of telomere addition in macronuclear DNA do not contain $\mathrm{C}_{4} \mathrm{~A}_{2}$ repeats, and they are not utilized by telomerase in vitro (Spangler et al. 1988). This result suggests that there may be other telomerase recognition sequences proximal to the sites of telomere addition in Tetrahymena macronuclear chromosomes. In human, healing of broken chromosomes results from the addition of $\left(\mathrm{C}_{3} \mathrm{TA}_{2}\right)_{n}$ at nontelomeric ends distal to telomerelike sequences (Wilkie et al. 1990). In yeast, heterologous telomeric sequences are sufficient for the telomere elongation reaction without having to be positioned at the termini of linear molecules (Murray et al. 1988). On the other hand, in vitro data indicate that specific priming is sufficient for telomere extension by telomerase (Greider and Blackburn 1987). It is conceivable that telomerase may contain distinct anchoring and polymerizing domains, both of which contribute to the telomere extension process.

Recently, Wang and Zakian (1990) showed that transfer of heterologous telomeric sequences from one telomere to another can occur at or near the junction of telomeric and nontelomeric DNA via a "copy-choice". type recombination mechanism. They suggested that such a mechanism would provide yeast with an immediate rescue of short termini. This recombination mode of telomere regeneration also requires a protein that binds specifically to telomeric junctions. TBF $\alpha$ is an obvious candidate for such a protein in this model.

If $\mathrm{TBF} \alpha$ serves as an anchor for enzymes important for the regeneration of telomeres, one would expect terminal junction sequences to play an important role in the regeneration of telomeres in yeast. Thus, previous observations that subtelomeric $X$ sequences do not play significant roles in telomere function because they can be substituted by a number of heterologous telomeric repeat sequences may be interpreted differently. Our data suggest that heterologous telomeric sequences may be perfect substitutes for the subtelomeric junction sequences, as all of them contain the sequence motif ACCC(T/C)AA. Perhaps in yeast, the irregular telomeric sequence does not serve well as a specific binding site for telomerase and so an upstream sequence is used instead. Clearly, we are far from understanding the molecular details of how yeast might regenerate its telomeres, and the models presented here are built on limited informa- 
tion from one of many proteins that interact with telomeres (J. Coran, E. Epstein, and V. Vogt, pers. comm.). This study of TBF $\alpha$ provides us with a working hypothesis to investigate how yeast might synthesize its telomeres.

\section{Materials and methods}

Strains and plasmids

The Saccharomyces cerevisiae strain B)2168 (MATa pep4-3 prc1-407 prb-1122 ura3-52 trp1 leu2) was used for the purification of TBF $\alpha$, and RAP1 from yeast. E. coli strain BL21 $\left(F^{-}\right.$ ompT $r b^{-} \mathrm{mb}^{-}$) was used for the overexpression of RAPl protein. pRHE3 and pCHE3 were constructed by inserting the $0.52-\mathrm{kb}$ HindIII-EcoRI fragment from p120.23 (gift from Dr. J. Abraham) into the polylinker sites of YRp74 and YCp86, respectively. pRYT3 and pCYT3 were constructed by inserting the 0.7-kb yeast telomeric sequence from MTLB6SD21-66 (Button and Astell 1986) into the polylinker sites of YRp74 and YCp86, respectively. Plasmid pBHTl was derived from the cloning of $250 \mathrm{bp}$ of EcoRI-HindIII fragment from pNC50 (Schechtman 1987), which contains 162 bp of poly $\left(\mathrm{C}_{3} \mathrm{TA}_{2}\right.$ ), into the same sites in Bluescript KS - phagemid. Plasmids pCAJ123 and pCAJ63 (Longtine et al. 1989) contain 27 bp of $X$ sequence in addition to 138 and $63 \mathrm{bp}$ of poly $\left(\mathrm{C}_{1-3} \mathrm{~A}\right)$, respectively, which are deletion derivatives of telomere clone 120 /Chan and Tye 1983b). pDel5 is a plasmid that carries $300 \mathrm{bp}$ of poly $\left(\mathrm{C}_{4} \mathrm{~A}_{2}\right)$ (gift from J. Szostak). Plasmid pTEF-2 contains the UAS of TEF2 gene (Shore et al. 1987).

\section{Oligonucleotides}

All oligonucleotides used in this study were made by Cornell Biotechnology Facility or Operon Technologies, Inc. The actual sequences are listed below:

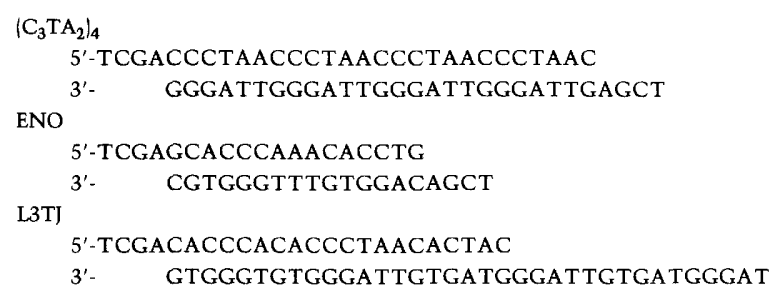

\section{Agarose gel band-shift assay}

The agarose gel band-shift assay was essentially the same as described previously (Berman et al. 1987), with the following modifications. The glycerol content in the binding reaction was adjusted to $10 \%$ (vol/vol). The radiolabeled DNA probes (both annealed oligonucleotide and restriction fragment) used in the binding reaction were between 2 and 5 fmoles, and the nonspecific competitor was $1-3 \mu \mathrm{g}$ sonicated E. coli DNA. Plasmid probes (i.e., EcoRI- and HindIII-digested pBHTl, XhoI- and BamHI-digested pDel5, EcoRI- and HindIII-digested pTEF-2) were end-labeled with an $\left[\alpha^{32} \mathrm{P}\right] \mathrm{dNTP}$ using reverse transcriptase (Molecular Genetics Resources) according to vendor-recommended procedure. One unit of DNA-binding activity is defined as the binding (or shifting) of 1 fmole of ${ }^{32} \mathrm{P}$-labeled DNA fragment containing a single recognition site in the band-shift assay, measured within the linear range of the assay. Activity for $\operatorname{TBF} \beta$ was estimated based on binding to $\operatorname{poly}\left(\mathrm{C}_{1-3} \mathrm{~A}\right) \cdot \mathrm{X}$, which contains multiple binding sites. Unit calculation was based on densitometric (Bio-Rad) scanning of the shifted and unshifted bands on autoradiograms.

\section{Mitotic stability assay}

$\mathrm{Ura}^{+}$transformation carrying various plasmids was grown selectively in liquid medium overnight and diluted into YEPD medium at a density of $1 \times 10^{5}$ cells $/ \mathrm{ml}$. After $10-12$ generations of growth, cells were plated out on YEPD and CM-uracil plates at appropriate dilutions. The percentage of cells carrying the plasmid was defined as the ratio of the number of colonies that grew on CM-uracil plates to those on YEPD plates. For each plasmid construct, four to six independent transformants were assayed to derive the mean and the standard deviation.

\section{Purification of TBF $\alpha$ and RAP1 from yeast}

Yeast cells $(\mathrm{BJ} 2168)$ were grown in YEPD in a $30^{\circ} \mathrm{C}$ air shaker and harvested at mid-log phase by centrifugation. The cell paste was washed once with $100 \mathrm{~mm} \mathrm{KCl}$ buffer A [50 mM HEPES ( $\mathrm{pH}$ 7.5), $1 \mathrm{mM}$ EDTA, $1 \mathrm{mM}$ DTT, $10 \%$ glycerol], rapidly frozen in liquid nitrogen, and stored at $-70^{\circ} \mathrm{C}$. The frozen cells were lysed by a Waring Blendor procedure (Sorger et al. 1989), resulting in a fine yeast powder. The powder was hydrated by adding $100 \mathrm{mM} \mathrm{KCl}$ buffer $\mathrm{A}(2.0 \mathrm{ml} / \mathrm{g}$ yeast powder) supplemented with $5 \mathrm{mM} \mathrm{MgCl}_{2}$ and protease inhibitors $(0.2 \mu \mathrm{M}$ PMSF, $2.0 \mathrm{mM}$ pepstatin A, $0.5 \mu \mathrm{M}$ leupeptin, and $0.5 \mu \mathrm{g} / \mathrm{ml}$ antipain), and warmed up to $4^{\circ} \mathrm{C}$ (all subsequent steps were carried out at $4^{\circ} \mathrm{Cl}$. The unlysed cells and cell debris were removed by centrifugation $(8000 \mathrm{~g}, 15 \mathrm{~min})$, and the lysate was cleared further by ultracentrifugation $(100,000 \mathrm{~g}, 60 \mathrm{~min})$. The supernatant was then subjected to ammonia sulfate fractionation. The precipitate, salted out from $25 \%$ to $50 \%$ ammonium sulfate saturation (fraction II), was redissolved in $50 \mathrm{~mm} \mathrm{KCl}$ buffer A containing protease inhibitors and dialyzed in $400 \times$ volume of $150 \mathrm{~mm} \mathrm{KCl}$ buffer A for $2 \mathrm{hr}$. After adjusting the salt concentration, the dialyzed fraction II was loaded onto a phosphocellulose column (CF11, Whatman). The column was developed with a linear salt gradient of $150-600 \mathrm{mM} \mathrm{KCl}$ in buffer $\mathrm{A}$. The fractions containing TBF $\alpha$ DNA-binding activity were pooled and diluted with buffer $\mathrm{N}$ (buffer A supplemented with $0.05 \%$ NP-40 and 0.2 mM PMSF|, and loaded onto a pBHT1 DNA-cellulose column $(10 \mathrm{ml})$ equillibrated in $100 \mathrm{mM} \mathrm{KCl}$ buffer $\mathrm{N}$, which was prepared by linearizing PBHT1 with EcoRI digestion and coupled to cellulose as described (Alberts and Herrick 1971). After washing with $30 \mathrm{ml}$ of $100 \mathrm{~mm} \mathrm{KCl}$ buffer $\mathrm{N}$, the loaded column was developed with a $30-\mathrm{ml}$ linear gradient of $100-300 \mathrm{mM} \mathrm{KCl}$ in buffer $\mathrm{N}$, followed by a step wash of $30 \mathrm{ml}$ buffer $\mathrm{N}$ containing $300 \mathrm{mM} \mathrm{KCl}$, and another $30-\mathrm{ml}$ linear gradient of $300-600 \mathrm{mM} \mathrm{KCl}$ in buffer $\mathrm{N}$. The elution of TBF $\alpha$ and RAP1 was monitored by band-shift assay described above. The phosphocellulose column fractions containing RAP1 DNAbinding activity were pooled and purified further on a DNA affinity column as described (Buchman et al. 1988b), except that the oligonucleotide coupled to CNBr-activated Sepharose 4B resin (Pharmacia) corresponds to the RAPl-binding site within the UASs of yeast ENO gene.

\section{DNase I footprinting analysis}

The DNA sequences protected by TBF $\alpha$ and RAP1 binding were analyzed by DNase I footprinting technique (Johnson et al. 1979). The yeast telomere probe from the plasmid pCAJ63 was prepared by labeling the C-rich strand at the FokI end and the G-rich strand at the EcoRI end by filling-in with $\left[\alpha-{ }^{32} \mathrm{P}\right] \mathrm{dATP}$ using reverse transcriptase (Molecular Genetic Resources). The 
DNase I cleavage pattern was resolved on a $8 \mathrm{M}$ urea- $-8 \%$ polyacrylamide gel. The Maxam-Gilbert sequencing ladders were generated by the standard method (Maxam and Gilbert 1980).

\section{Acknowledgments}

We thank Volker Vogt for his critical reading of the manuscript. We thank Bristol Myers Squibb Industrial Division for growing large-scale yeast cultures for us. This work was supported by grants from the American Cancer Society and the Cornell University Biotechnology Program, which is sponsored by the New York State Science and Technology Foundation, a consortium of industries, the U.S. Army Research Office, and the National Science Foundation.

The publication costs of this article were defrayed in part by payment of page charges. This article must therefore be hereby marked "advertisement" in accordance with 18 USC section 1734 solely to indicate this fact.

\section{References}

Alberts, B. and G. Herrick. 1971. DNA-cellulose chromatography. Methods Enzymol. 21: 192-213.

Bateman, A.J. 1975. Simplification of palindromic telomere theory. Nature 253: 379.

Berman, J., S. Eisenberg, and B.-K. Tye. 1987. An agarose gel assay that permits detection of DNA binding proteins in yeast cell extracts. Recombinant DNA, Part F. Methods Enzymol. 155: 528-537.

Berman, J., C.Y. Tachibana, and B.-K. Tye. 1986. Identification of a telomere-binding activity from yeast. Proc. Natl. Acad. Sci. 86: 3713-3717.

Brand, A.H., G. Micklem, and K. Nasmyth. 1987. A yeast silencer contains sequences that can promote autonomous plasmid replication and transcriptional activation. Cell 51: 709-719.

Brown, W.R. 1989. Molecular cloning of human telomeres in yeast. Nature 338: 774-776.

Buchman, A.R., W.J. Kimmerly, J. Rine, and R. Kornberg. 1988a. Two DNA-binding factors recognize specific sequences at silencers, upstream activating sequences, autonomously replicating sequences, and telomeres in Saccharomyces cerevisiae. Mol. Cell. Biol. 8: 210-225.

Buchman, A.R., N.F. Lue, and R.D. Kornberg. 1988b. Connections between transcriptional activators, silencers, and telomeres as revealed by functional analysis of a yeast DNAbinding protein. Mol. Cell. Biol. 8: 5086-5099.

Button, L.L. and C.R. Astell. 1986. The Saccharomyces cerevisiae chromosome III left telomere has a type $\mathrm{X}$, but not a type $\mathrm{Y}^{\prime}$, ARS region. Mol. Cell. Biol. 6: 1352-1356.

Cavalier-Smith, T. 1974. Palindromic base sequences and replication of eukaryote chromosomes ends. Nature 250: 467470.

Chan, C.S.M. 1985. Chromosome structure of yeast: Replication origins and telomeres. Ph.D. Thesis. Cornell University, Ithaca.

Chan, C.S.M. and B.K. Tye. 1983a. Organization of DNA sequences and replication origins at yeast telomeres. Cell 33: $563-573$.

_ 1983b. A family of Saccharomyces cerevisiae repetitive autonomously replicating sequences that have very similar genomic environments. J. Mol. Biol. 168: 505-523.

Cross, S.H., R.C. Allshire, S.J. McKay, N.I. McGill, and H.J. Cooke. 1989. Cloning of human telomeres by complementation in yeast. Nature 338: $771-774$.
Dancis, B.M. and G.P.Holmquist. 1979. Telomere replication and fusion in eukaryotes. I. Theoret. Biol. 78: 211-224.

Dunn, B., P. Szauter, M.L. Pardue, and J. Szostak. 1984. Transfer of yeast telomeres to linear plasmids by recombination. Cell 39: $191-201$.

Gottschling, D.E. and T.R. Cech. 1984. Chromatin structure of the molecular ends of Oxytricha macronuclear DNA: Phased nucleosomes and a telomeric complex. Cell 38: $501-510$.

Gottschling, D.E. and V.A.Zakian. 1986. Telomere proteins: Specific recognition and protection of the natural termini of Oxytricha macronuclear DNA. Cell 47: 195-205.

Greider, C.W. and E.H. Blackburn. 1985. Identification of a specific telomere terminal transferase activity in Tetrahymena extracts. Cell 43: 405-413.

- 1987. The telomere terminal transferase of Tetrahymena is a ribonucleoprotein enzyme with two kinds of primer specificity. Cell 51: 887-898.

-1989. A telomeric sequence in the RNA of Tetrahymena telomerase required for telomere repeat synthesis. Nature 337: 331-337.

Hofmann, J. F.-X., T. Laroche, A. Brand, and S.M.Gasser. 1989. RAP-1 factor is necessary for DNA loop formation in vitro at the silent mating type locus HML. Cell 57: 725-737.

Horowitz, H. and J.E. Haber. 1985. Identification of autonomously replicating circular subtelomeric $\mathrm{Y}^{\prime}$ elements in Saccharomyces cerevisiae. Mol. Cell. Biol. 5: 2369-2380.

Jager, D. and P. Philippsen. 1989. Many yeast chromosomes lack the telomere-specific $\mathrm{Y}^{\prime}$ sequence. Mol. Cell. Biol. 9: $5754-5757$.

Johnson, A.D., B.J. Meyer, and M. Ptashne. 1979. Interactions between DNA-bound repressors govern regulation by the $\lambda$ phage repressor. Proc. Natl. Acad. Sci. 76: 5061-5065.

Kimmerly, W.J. and J. Rine. 1987. Replication and segregation of plasmids containing cis-acting regulatory sites of silent mating-type genes in Saccharomyces cerevisiae are controlled by the SIR genes. Mol. Cell. Biol. 7: 4225-4237.

Longtine, M.S., N.M. Wilson, M.E. Petracek, and J. Berman. 1989. A yeast telomere binding activity binds to two related telomere sequence motifs and is indistinguishable from RAP1. Curr. Genet. 16: 225-239.

Lundblad, V. and E. Blackburn. 1990. RNA-dependent polymerase motifs in EST1: Tentative identification of a protein component of an essential yeast telomerase. Cell 60: 529530.

Lundblad, V. and J.W. Szostak. 1989. A mutant with a defect in telomere elongation leads to senescence in yeast. Cell 57: 633-643.

Maxam, A. and W. Gilbert. 1980. Sequencing end-labelled DNA with base-specific chemical cleavages. Methods Enzymol. 65: 499-560.

McClintock, B. 1941. The stability of broken ends of chromosomes in Zea Mays. Genetics 26: 234-282.

Morin, G.B. 1989. The human telomere terminal transferase enzyme is a ribonucleoprotein that synthesizes TTAGGG repeats. Cell 59: 521-529.

Murray, A.W., T.E. Claus, and J.W. Szostak. 1988. Characterization of two telomeric DNA processing reactions in Saccharomyces cerevisiae. Mol. Cell. Biol. 8: 4642-4650.

Pluta, A.F. and V.A. Zakian. 1989. Recombination occurs during telomere formation in yeast. Nature 337: 429-433.

Pluta, A.F., G.M. Dani, B.B. Spear, and V. Zakian. 1984. Elaboration of telomeres in yeast: Recognition and modification of termini from Oxytricha macronuclear DNA. Proc. Natl. Acad. Sci. 81: 1475-1479.

Richards, E.J. and F.M. Ausubel. 1988. Isolation of a higher eu- 
karyotic telomere from Arabidopsis thaliana. Cell 53: 127136.

Schechtman, M.G. 1987. Isolation of telomere DNA from Neurospora crassa. Mol. Cell. Biol. 7: 3168-3177.

Shampay, J., J.W. Szostak, and E.H. Blackburn. 1984. DNA sequences of telomeres maintained in yeast. Nature 310: 154-157.

Shore, D. and K.A. Nasmyth. 1987. Purification and cloning of a DNA binding protein from yeast that binds to both silencer and activator elements. Cell 51: 721-732.

Shore, D., D.J. Stillman, A.H. Brand, and K.A. Nasmyth. 1987. Identification of silencer binding proteins from yeast: Possible roles in $S I R$ control and DNA replication. EMBO $\%$. 6: 461-467.

Sorger, P.K., G. Ammerer, and D. Shore. 1989. Identification and purification of sequence-specific DNA-binding proteins. In Protein function, a practical approach led. T.E. Creighton), pp. 199-223. IRL, Oxford.

Spangler, E.A., Ryan, T. and Blackburn, E.H. 1988. Developmentally regulated telomere addition in Tetrahymena thermophila. Nucleic Acids Res. 16: 5569-5585.

Surosky, R.T., S.C. Newlon, and B.-K. Tye. 1986. The mitotic stability of deletion derivatives of chromosome III in yeast. Proc. Natl. Acad. Sci. 83: 414-418.

Szostak, J.W. and E.H. Blackburn. 1982. Cloning yeast telomeres on linear plasmid vectors. Cell 29: 245-255.

Walmsley, R.W., C.S.M. Chan, B.-K. Tye, and T.D. Petes. 1984. Unusual DNA sequences associated with the ends of yeast chromosomes. Nature 310: 157-160.

Wang, S.S. and V.A.Zakian, 1990. Telomere-telomere recombination provides an express pathway for telomere acquisition. Nature 345: 456-458.

Watson, J.D. 1972. Origin of concatemeric T7 DNA. Nat. New Biol. 239: 197-201.

Wilkie, A.O.M., J. Lamb, P.C. Harris, R.D. Finney, and D.R. Higgs. 1990. A truncated human chromosome 16 associated with $\alpha$ thalassaemia is stabilized by addition of telomeric repeat (TTAGGG)n. Nature 346: 868-871. 


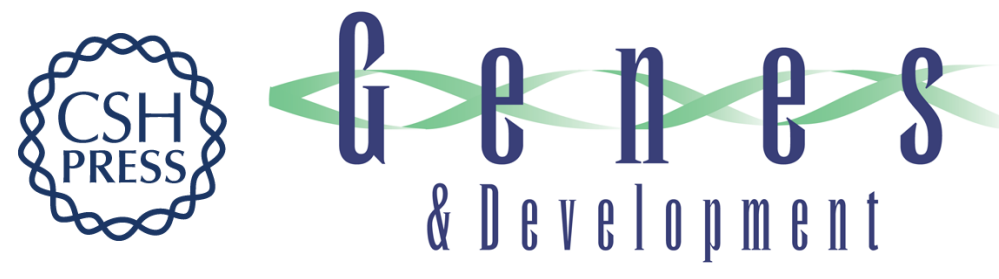

\section{A yeast protein that binds to vertebrate telomeres and conserved yeast telomeric junctions.}

Z P Liu and B K Tye

Genes Dev. 1991, 5:

Access the most recent version at doi:10.1101/gad.5.1.49

References This article cites 46 articles, 11 of which can be accessed free at:

http://genesdev.cshlp.org/content/5/1/49.full.html\#ref-list-1

License

Email Alerting Receive free email alerts when new articles cite this article - sign up in the box at the top Service right corner of the article or click here.

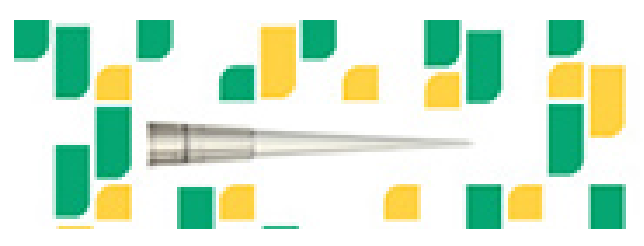

Focused on your science. 